\author{
Katarzyna Bieniek \\ Uniwersytet Jagielloński \\ kasiaclio@onet.pl
}

\title{
Dysfunkcje rodziny, a piecza zastępcza
}

\author{
Family dysfunctions and foster care
}

\begin{abstract}
STRESZCZENIE
W artykule zostały omówione zagadnienia dobra dziecka, dysfunkcji rodziny oraz pieczy zastępczej w polskim systemie prawnym. W pracy opisano znaczenie rodziny, jej funkcji oraz roli w życiu każdego dziecka. Przybliżono problem dysfunkcji rodziny, niewłaściwych postaw i zachowań rodzicielskich. Ponadto przedstawiono instytucję pieczy zastępczej jako formę pomocy rodzinie stosowaną w przypadku braku należytej pieczy rodzicielskiej oraz naruszenia zasady dobra dziecka.
\end{abstract}

Słowa kluczowe: dobro dziecka, rodzina, dysfunkcje rodziny, piecza zastępcza

\section{POJĘCIE RODZINY ORAZ DYSFUNKCJONALNOŚCI}

Zgodnie z art. 2 ustawy o Rzeczniku Praw Dziecka „dzieckiem jest każda istota ludzka od poczęcia do osiągnięcia pełnoletności”, a jego najważniejszymi opiekunami są rodzice. Dziecko wspólnie z rodzicami tworzy rodzinę, która jest najstarszą i najpowszechniejszą formą życia społecznego, spotykaną we wszystkich epokach, kulturach i społeczeństwach. Pojęcie rodziny nie zostało zdefiniowane w ustawodawstwie zwykłym ${ }^{1}$, jednakże wskazać należy, iż rodzina jest pierwszym, naturalnym środowiskiem i grupą społeczną ${ }^{2}$ dla dziecka. Definiując pojęcie rodziny można ją określić jako zbiorowość ludzi, grupę społeczną powiązaną ze sobą więzią małżeństwa, pokrewieństwa, powinowactwa czy adopcji. Według Z. Zaborowskiego rodzina to grupa naturalna oparta na związkach krwi małżeństwa lub adopcji.

1 Zob. A. Mączyński, Konstytucyjne podstawy prawa rodzinnego, Warszawa 2012, s. 765 in.

2 Zob. J. Rembowski, Więzi uczuciowe w rodzinie, Warszawa 1972; Tegoż: Rodzina w świetle psychologii, PZWS 1984, M. Ziemska, [w:] Patologia rodziny, Zagadnienia patologii społecznej, red. A. Podgórecki, Warszawa 1976. 
Jest to grupa o charakterze wspólnoty, której podstawową funkcją jest utrzymanie ciągłości biologicznej społeczeństwa ${ }^{3}$.

Podstawową normą konstytucyjną odnoszącą się do rodziny jest art. 18 Konstytucji $\mathrm{RP}^{4}$. Zgodnie z treścią przedmiotowej regulacji prawnej rodzina znajduje się pod ochroną i opieką Rzeczypospolitej Polskiej. Ustawodawca, ustanawiając w art. 18 Konstytucji RP ochronę i opiekę rodziny, realizuje w ten sposób wyznaczniki natury politycznej zawarte w treści Preambuły Konstytucji RP ${ }^{5}$. Rodzina jako związek rodziców i dzieci bez wątpienia stanowi wspólnotę, mającą pierwszorzędne znaczenie dla bytu i funkcjonowania społeczeństwa jako naturalny i niezastąpiony element struktury społecznej ${ }^{6}$ Odgrywa ona pierwszorzędną rolę w kontekście przyszłych pokoleń. Jednakże, gdy rodziców zabraknie lub nie wywiązują się oni ze swoich obowiązków rodzicielskich, nie dają sobie samodzielnie rady z opieką nad dzieckiem, to właśnie państwo w myśl zasady pomocniczości ${ }^{7}$ musi im pomóc, „przejąć” ich obowiązki, albowiem dzieci są największym bogactwem każdego społeczeństwa. W kwestii pomocy rodzinie, przestrzeganie zasady pomocniczości ma walor nie tylko finansowo-organizacyjny, ale przede wszystkim społeczno -wychowawczy, albowiem wpływa na podtrzymanie więzi rodzinnej z dzieckiem i mobilizuje rodziców do odpowiedzialności za los dziecka i rodziny ${ }^{8}$.

Współcześnie w większości rodzin występują elementy niewłaściwych sytuacji życia rodzinnego oraz postaw i zachowań rodzicielskich. W rodzinie dysfunkcyjnej obserwujemy zaburzenia stosunków emocjonalnych i interpersonalnych między rodzicami, a dziećmi. Rodzina dysfunkcyjna nie radzi sobie z kryzysami rozwojowymi, brakuje w niej poczucia bezpieczeństwa, jasnego określenia norm i wartości. Rodzina dysfunkcyjna to rodzina, która nieprawidłowo wypełnia swoje funkcje albo świadomie lub nieświadomie nie spełnia funkcji wyznaczonych jej przez społeczeństwo. ${ }^{9}$ $\mathrm{W}$ rodzinie dysfunkcjonalnej mamy do czynienia $\mathrm{z}$ brakiem zaspokajania potrzeb psychicznych dziecka, brakiem celów wychowawczych, życiowych, a metody opiekuńczo-wychowawcze występujące w takiej rodzinie są okazjonalne, niepedago-

\footnotetext{
3 Z. Zaborowski, Rodzina jako grupa społeczno-wychowawcza, Warszawa 1980, s.71.

4 Konstytucja Rzeczypospolitej Polskiej z dnia 2 kwietnia 1997r., (t.j. Dz. U. z 1997r., Nr 78, poz. 483 z zm.), Zob. M. Safjan, L. Bosek, Komentarz do art. 18 Konstytucji RP, Konstytucja RP. Tom I. Komentarz., Legalis 2016.

5 Rodzina i prawo, red. D. Jaroszewskiej - Choraś, A. Kilińskiej - Pękacz, A. Wedeł - Domaradzkiej, Bydgoszcz 2017, s. 18.

6 W. Borysiak, [w:] Komentarz do art. 18 Konstytucji RP, Konstytucja RP. Tom I. Komentarz do art. 1-86, red. M. Safjan, L. Bosek, Warszawa 2016.

7 Zob. M. Andrzejewski, [w:] Pomocnicza rola państwa w świetle konwencji o prawach dziecka, Współczesne kierunki w opiece nad dzieckiem, red. Z. W. Stelmaszuka, Warszawa 1999, s. 110.

8 T. Smyczyński, Prawo rodzinne i opiekuńcze, Warszawa 2016, s. 258.

9 A. Kotlarska-Michalska, [w:] Główne cechy rodzin dysfunkcyjnych i możliwości zintegrowania pomocy środowiskowo - instytucjonalnej, Zintegrowane działania oświaty i pomocy społecznej na rzecz polityki społecznej, „Biuletyn Informacyjny Służb Socjalnych” nr 1(4), Poznań 1997a.
} 
giczne, przejawiające się w niedostosowaniu dziecka do potrzeb, wartości i celów społecznych ${ }^{10}$. Wielość definicji próbujących określić rodzinę dysfunkcyjną pokazuje, że termin ten jest pojęciem nieostrym albowiem mieszczą się w nim rodziny, które posiadają jedną dysfunkcję jak i rodziny charakteryzujące się jednocześnie wieloma dysfunkcjami ${ }^{11}$. Według T. Sakowicza, rodziny dysfunkcjonalne, to rodziny niepewne i zagubione wobec własnych zadań, wątpiące niekiedy w znaczenie prawdy życia małżeńskiego i rodzinnego. Są to również rodziny, w których jednostki napotykają przeszkody w korzystaniu ze swoich podstawowych praw na skutek nieprawidłowości panujących w rodzinie ${ }^{12}$. Eliminowanie trudności wychowawczych u dzieci $\mathrm{z}$ rodzin dysfunkcyjnych nie jest łatwe, albowiem przebywają one w niewydolnym wychowawczo-opiekuńczym środowisku o zaburzonych oddziaływaniach socjalizacyjnych i emocjonalnych, w środowisku gdzie spotykamy się ze zjawiskiem rozbitej wspólnoty członków rodziny gdzie podstawowa więź emocjonalna między rodzicami, a dzieckiem zostaje osłabiona ${ }^{13}$.

\section{PRZYCZYNY DYSFUNKCJI RODZINY}

Samo określenie przyczyn dysfunkcji rodziny jest dość trudnym zadaniem, gdyż jej tworzenie jest procesem, który rozpoczyna się zaburzeniem jednej funkcji rodzicielskiej, wywołując inne, niekorzystne sytuacje życia rodzinnego. Według M. Jarosza, określenie dezintegracji rodziny dotyczy stanu, w którym jeden lub więcej członków nie spełnia przypisanych im ról społecznych ${ }^{14}$. Przyczyn dysfunkcjonalności rodziny należy doszukiwać się w dwóch grupach uwarunkowań zarówno zewnętrzno-rodzinnych jak i wewnętrzno-rodzinnych kumulujących się ze sobą i tworzących złożony splot przyczyn i zaburzeń w wypełnianiu zadań rodzicielskich, a powodujących dysfunkcjonalność rodziny o różnym stopniu i zakresie ${ }^{15}$. Do pierwszej kategorii dysfunkcjonalności rodziny należy zaliczyć przyczyny związane ze zjawiskiem makrostruktury społecznej takie jak: ubóstwo, bezrobocie, zmiany w porządku aksjonormatywnym, marginalizacja, wykluczenie, kryzys gospodarczy, niski poziom ekonomiczny społeczeństwa, a także niski poziom kultury pedagogicz-

10 Zob. J. Szczepański, Elementarne pojęcie socjologii, Warszawa 1970, s. 334; red. L. Maślackiej, Rodziny dysfunkcjonalne, Wrocław 1991, s. 3.

11 A. Kotlarska - Michalska, Dysfunkcje rodziny jako efekt przemian makrostrukturalnych, Toruń 2011, s. 16.

12 T. Sakowicz, Dysfunkcjonalność rodziny a resocjalizacja (Wybrane teksty z socjologii rodziny i resocjalizacji), Kraków 2006, s. 37.

13 H. Cudak, Dysfunkcje rodziny i jej zagrożenia opiekuńczo-wychowawcze, „Pedagogika Rodziny 1/2”, 2011, s.14.

14 M. Jarosz, Problemy dezorganizacji rodziny, Warszawa 1979, s. 20-41.

15 H. Cudak, op. cit., s. 10. 
nej społeczeństwa. Ponadto, konflikty społeczne, degradacja wartości społecznych, migracja ludności w społeczeństwie, wzrost tolerancji i dewaluacji norm społecznych, niedoskonałość systemu publicznej pomocy społecznej oraz przenikanie wzorców zachowań, często jakże, niekorzystnych z państw Europy Zachodniej, a także Stanów Zjednoczonych. W wielu pracach socjologicznych i pedagogicznych wskazuje się również, że źródłem dysfunkcji rodziny jest kultura masowa, która zachęca do przyjemniejszych form spędzania czasu niż wywiązywanie się z moralnych zobowiązań wobec rodziny ${ }^{16}$. Do przyczyn dysfunkcjonalności tkwiących w środowisku rodzinnym należy zaliczyć niewydolności opiekuńczo-wychowawcze rodziny, konflikty w rodzinie, alkoholizm jednego bądź obojga rodziców, uzależnienie od narkotyków rodziców, niską kulturę pedagogiczną rodziców, ubóstwo materialne rodziny, przestępczość rodziców, rozbicie struktury rodzinnej, rozluźnienie, a nawet brak więzi emocjonalnej w rodzinie, traumatyczną atmosferę życia domowego oraz negatywne postawy rodzicielskie i cechy osobowe rodziców. Do przejawów patologii i dewiacji społecznej powodującej dysfunkcjonalność rodziny zaliczamy również zachowania autodestrukcyjne, dewiacje zachowań seksualnych, zaburzenia psychiczne, chorobę fizyczną, kalectwo, rozbicie rodziny, układ nieformalny związku, a mianowicie konkubinat, złe pożycie rodziców, a także ich patologiczne zachowania w stosunku co do dziecka niejednokrotnie przejawiające się stosowaniem wobec niego przemocy. Kolejną przyczyną dysfunkcyjności w rodzinie są konflikty utożsamiane z walką, wzajemnym wyrządzaniem sobie przykrości, utrudnianiem życia ${ }^{17}$.

\section{DOBRO DZIECKA}

Dobro dziecka ${ }^{18}$ odgrywa pierwszoplanową rolę przy wykładni przepisów Kodeksu rodzinnego i opiekuńczego. Mimo, że nie ma definicji ustawowej tego pojęcia, za J. Ignaczewskm ${ }^{19}$ wskazać należy, iż dobro dziecka jest zespołem wartości zarówno duchowych oraz materialnych, koniecznych dla prawidłowego rozwoju fizycznego i moralnego dziecka, a nadto, iż koresponduje z pojęciem nadrzędnego

16 M. Żardecka - Nowak, [w:]Czy we współczesnej liberalnej demokracji jest miejsce dla wartości rodzinnych? red. M. Malikowski, S. Gałkowski, Zagrożenia dla rodziny, Rzeszów 2010.

17 S. Kozak, Patologia eurosieroctwa w Polsce, Skutki migracji zarobkowej dla dzieci i ich rodzin, Warszawa 2010, s. 83; Zob. Z. Radwański, Pojęcie i funkcja „dobra dziecka” w polskim prawie rodzinnym i opiekuńczym, „Studia Cywilistyczne”, t. XXXI, Warszawa - Kraków 1981, s. 18.; M. Balcarek, Prawa dziecka, Warszawa 1988, s. 22.; M. Zieliński, Z. Ziembiński, Uzasadnienie twierdzeń, ocen i norm w prawoznawstwie, Warszawa, 1988, s. 136-137.

18 Zob. K. Piotrowska, Dobro Dziecka w orzecznictwie sędziego rodzinnego, „IUSTITIA” 2017, Nr 1.

19 H. Ciepła, J. Ignaczewski, J. Skibińska-Adamowicz, Komentarz do spraw rodzinnych, Warszawa 2012, s. 228. 
interesu dziecka rekonstruowanego na podstawie przepisów Konwencji o prawach dziecka z dnia 20 listopada 1989 roku. W myśl przepisu art. 3 Konwencji o prawach dziecka ${ }^{20}$, nadrzędną sprawą we wszystkich działaniach dotyczących dzieci, podejmowanych przez publiczne lub prywatne instytucje opieki społecznej, sądy, władze administracyjne lub ciała ustawodawcze, jest najlepsze zabezpieczenie interesów dziecka. Dobro dziecka jest podstawowym zagadnieniem prawa rodzinnego, a jego ochrona stanowi jedną z kluczowych zasad systemu prawa. Samo pojęcie „dobra dziecka” nie zostało zdefiniowane przez ustawodawcę jednakże, w literaturze przedmiotu można znaleźć próby jego określenia. Tytułem przykładu, według S. Kołodziejskiego ${ }^{2 l}$ dobro dziecka należy traktować jako „zespół wartości, zarówno duchowych, jak i materialnych, jakie konieczne są do prawidłowego: rozwoju fizycznego dziecka, rozwoju duchowego dziecka, i to w jego aspekcie zarówno intelektualnym, jak i moralnym, należytego przygotowania go do pracy dla dobra społeczeństwa". W innym źródle stwierdzono też, że pojęcie to należy do tzw. swoistych pojęć prawnych nienadających się do definiowania, ponieważ nie mają one żadnego semantycznego odniesienia i nie oznaczają ani faktów, ani relacji, ani procesów ${ }^{22}$. Podkreślano przy tym, że jest to model idealizacyjny, zakładający, że dziecko wychowuje się w rodzinie, w atmosferze miłości w warunkach pozwalających zaspokoić jego rozsądnie rozumiane potrzeby oraz najpełniej rozwijać jego talenty i zdolności ${ }^{23}$. W. Stojanowska wykazała, iż termin „dobro dziecka" w rozumieniu prawa rodzinnego oznacza kompleks wartości o charakterze niematerialnym i materialnym niezbędnym do zapewnienia prawidłowego rozwoju fizycznego i duchowego dziecka oraz do należytego przygotowania go do pracy odpowiednio do jego uzdolnień, a wartości te są zdeterminowane przez wiele czynników, na które ma wpływ aktualna sytuacja dziecka ${ }^{24}$. Przy wykładni pojęcia „dobra dziecka” znaczącą rolę odgrywa także doktryna i judykatura. Sąd Najwyższy w postanowieniu z dnia 11 lutego 1997 roku wskazał, że „pojęcie dobra dziecka z jednej strony obejmuje całą sferę najważniejszych jego spraw osobistych, przykładowo takich jak rozwój fizyczny i duchowy, odpowiednie kształcenie i wychowanie oraz przygotowanie do dorosłego życia, z drugiej zaś - ma ono wyraźny wymiar materialny polegający na konieczności zapewnienia dziecku środków do życia i realizacji celów o charakterze osobistym, a w wypadku gdy ma ono swój

${ }^{20}$ Konwencja o prawach Dziecka przyjęta przez Zgromadzenie Ogólne Narodów Zjednoczonych z dnia 20 listopada 1989r., (t. j. Dz. U. Z 1991r., Nr 120, poz. 526 z zm.).

21 S. Kołodziejski, Dobro wspólnych małoletnich dzieci jako przesłanka odmowy orzeczenia rozwodu, „Palestra”, Nr 9/1965, s. 30.

${ }^{22}$ Kodeks rodzinny i opiekuńczy z komentarzem, red. K. Piaseckiego, Warszawa 2002, s. 315316.

23 Por. Z. Radwański, op. cit., s. 19.

24 W. Stojanowska, Rozwód a dobro dziecka, Warszawa 1979, s. 21. 
majątek, także na dbałości o jego interes majątkowy"25. Ochrona dobra dziecka stanowi podstawową zasadę prawa rodzinnego wynikającą z art. 72 Konstytucji RP, który stanowi, iż: Rzeczpospolita Polska zapewnia ochronę praw dziecka. Każdy ma prawo żądać od organów władzy publicznej ochrony dziecka przed przemocą, okrucieństwem, wyzyskiem i demoralizacją. Wskazana zasada została także usankcjonowana w omawianym już art. 18 Konstytucji RP wyrażający zasadę ochrony rodziny. Ustawodawca w Konstytucji RP nadaje ochronie rodziny oraz ochronie dobra dziecka wysoką rangę, formułując ogólną zasadę konstytucyjną $\mathrm{w}$ art. 18 i przewidując $\mathrm{w}$ treści art. $72^{26}$ określone zabezpieczenie dla jej realizacji. Kluczową rolę natomiast, w kształtowaniu i zabezpieczeniu realizacji zasady dobra dziecka pełni sąd opiekuńczy poprzez osobę sędziego rodzinnego. Sędzia ten orzeka w sprawach szeroko rozumianego prawa dotyczącego rodziny. Sędzia rodzinny nie tylko kieruje postępowaniem sądowym i odpowiada za prawidłowe rozstrzygnięcie sprawy, ale nadzoruje wykonanie wyroku i dba o szybkie wykonanie orzeczenia, albowiem prawo nakłada na sędziego rodzinnego obowiązek współdziałania z organami, instytucjami i organizacjami społecznymi zajmującymi się na danym terenie problemami młodzieży, sprawami oświaty i wychowania oraz zdrowia ${ }^{27}$.

\section{ORZEKANIE O UMIESZCZENIU DZIECKA W PIECZY ZASTĘPCZEJ}

Mając na uwadze dobro dziecka oraz dobro społeczne Sąd opiekuńczy posiada możliwość ingerencji w sprawowanie władzy rodzicielskiej. W myśl art. 109 par. 1 kodeksu rodzinnego i opiekuńczego ${ }^{28}$ - ,jeżeli dobro dziecka jest zagrożone ${ }^{29}$, sąd opiekuńczy wyda odpowiednie zarządzenia”. Zgodnie z paragrafem 2 pkt 5 cytowanego przepisu Sąd może w szczególności zarządzić umieszczenie małoletniego w rodzinie zastępczej, rodzinnym domu dziecka albo w instytucjonalnej pieczy zastępczej albo powierzyć tymczasowo pełnienie funkcji rodziny zastępczej małżonkom lub osobie, niespełniającym warunków dotyczących rodziny zastępczych, w zakresie niezbędnych szkoleń, określonych w przepisach o wspieraniu rodziny i systemie pieczy zastępczej albo zarządzić umieszczenie małoletniego w zakładzie opiekuńczo-leczniczym, w zakładzie pielęgnacyjno-opiekuńczym lub w zakładzie rehabilitacji leczniczej. Należy zwrócić uwagę na fakt, iż umieszczenie dziecka w placówce opiekuńczo-wychowawczej to najbardziej surowe z pośród

25 Postanowienie SN z dnia 11 lutego 1997r., II CKN 90/96, Legalis nr 333272.

26 K. Piotrowska, op. cit., str. 11.

27 Problemy Opiekuńczo Wychowawcze, ,Instytut Rozwoju Służb Społecznych”, nr 5/2015, s. 6.

28 Ustawa z dnia 25 lutego 1964r. - Kodeks rodzinny i opiekuńczy, (t.j. Dz. U. z 2018r., poz. 950 ze zm.), dalej jako k.r.o.

29 Postanowienie SN z dnia 7 czerwca 1967r., III CR 84/67, OSCP 1968, nr 2, poz. 21. 
zarządzeń wymienionych $\mathrm{w}$ art. 109 k.r.o., albowiem zgodnie z obowiązującą doktryną przyjęta została zasada, wyrażona już wiele lat temu w orzecznictwie Sądu Najwyższego, która wskazuje, iż decydując się na rozstrzygnięcie o umieszczeniu dziecka w pieczy zastępczej Sąd opiekuńczy powinien mieć na uwadze, że regułą bardziej celową jest umieszczanie dziecka w pieczy zastępczej aniżeli w placówce opiekuńczo-wychowawczej, jak bowiem stwierdzają specjaliści, pobyt w takim zakładzie wywiera ujemny wpływ na psychikę dziecka, natomiast rodzina zastępcza stwarza dziecku - jeżeli tylko jest należycie dobrana - naturalne warunki rozwoju. Dodać należy, iż zastępcze środowisko rodzinne zapewnia dziecku warunki zbliżone do tych, jakie istnieją w normalnie funkcjonującej rodzinie naturalnej natomiast, pobyt dziecka w instytucjonalnej pieczy zastępczej w wyższym stopniu zagraża prawidłowemu rozwojowi dziecka, zwłaszcza jego psychiki i osobowości ${ }^{30}$. Pamiętać należy również, iż Sąd opiekuńczy orzekając o umieszczeniu dziecka w rodzinnej pieczy zastępczej jest obowiązany oznaczyć konkretną rodzinę zastępczą lub rodzinny dom dziecka. Sąd nie może przenieść swoich uprawnień w tej mierze na rzecz jednostki organizacyjnej pomocy społecznej, albowiem zgodnie ze stanowiskiem reprezentowanym przez Sąd Najwyższy - umieszczenie dziecka $\mathrm{w}$ jednej $\mathrm{z}$ form pieczy zastępczej jest najdalej idącą ingerencją $\mathrm{w}$ stosunki między rodzicami i dziećmi, a jednoczenie w prawa dziecka. Dlatego też, mając na względzie art. 48 ust. 2 oraz art. 72 Konstytucji RP koniecznością jest wydanie całościowego, a nie tylko blankietowego orzeczenia w danej sprawie. Podstawę skierowania dziecka do placówki opiekuńczo-wychowawczej stanowi orzeczenie Sądu, którego zgodnie ze stanowiskiem Sądu Najwyższego „obowiązkiem jest całościowe, kazuistyczne zbadanie potrzeb dziecka i dopasowanie do nich nie tylko formy piczy zastępczej, ale także osób, które będą tę pieczę wykonywać"31. W przypadku wydania orzeczenia przez Sąd opiekuńczy dziecko trafia do placówki na polecenie sędziego. W toku tego jakże, ciężkiego procesu odłączenia dziecka od biologicznych rodziców Sąd opiekuńczy zleca kuratorowi sądowemu przymusowe odebranie dziecka. W praktyce sądowej niewyobrażalne znaczenie ma właściwa współpraca nawiązująca się pomiędzy Sądem, a kuratorem sądowym oraz asystentem rodziny zarówno na etapie postępowania opiekuńczego-rozpoznawczego jak i na etapie postępowania wykonawczego, która pozwala zapobiec podjęciu zbyt pochopnej decyzji o umieszczeniu małoletniego w pieczy zastępczej. Aktualne uregulowania prawne i sposób współpracy Sądu z podmiotami działającymi na rzecz dziecka i rodziny stanowią dostateczną gwarancję uzyskania przez Sędziego miarodajnych informacji o rodzinie przed wydaniem orzeczenia.

\footnotetext{
30 J. Ignatowicz, M. Nazar, Prawo rodzinne, Warszawa 2016, s.166.

31 Uchwała SN (7) z dnia 14.11.2014 r., III CZP 65/14, Legalis.
} 


\section{PIECZA ZASTĘPCZA}

Piecza zastępcza jest właśnie formą pomocy rodzinie stosowaną w przypadku braku należytej pieczy rodzicielskiej, naruszenia zasady dobra dziecka, a regulowaną na mocy ustawy $z$ dnia 9 czerwca 2011 roku o wspieraniu rodziny i systemie pieczy zastępczej ${ }^{32}$. Przed wejściem w życie wskazanej ustawy podstawowe zasady organizacji wsparcia rodziny i zastępczej pieczy nad dzieckiem regulowały przepisy ustawy z dnia 12 marca 2004 roku o pomocy społecznej ${ }^{33} \mathrm{i}$ wydane na jej podstawie akty wykonawcze. Kodeks rodzinny i opiekuńczy, będący podstawowym aktem prawnym z dziedziny prawa rodzinnego, normował wówczas jedynie niektóre zagadnienia z pogranicza pieczy zastępczej i władzy rodzicielskiej oraz praw i obowiązków rodziców niezależnych od władzy rodzicielskiej ${ }^{34}$. Ustawa o wspieraniu rodziny i systemie pieczy zastępczej określa system pieczy zastępczej jako zespół osób, instytucji i działań mających na celu zapewnienie tymczasowej opieki i wychowania dzieciom w przypadkach niemożliwości sprawowania opieki i wychowania przez rodziców. Ponadto, normuje zasady i formy sprawowania pieczy zastępczej, zasady jej finansowania, pomocy w usamodzielnieniu jej pełnoletnich wychowanków oraz zadania administracji publicznej w tym zakresie.

Piecza zastępcza stanowi instrument prawny znajdujący zastosowanie w przypadkach gdy wszystkie formy pomocy rodzicom dziecka okazały się zawodne ${ }^{35}$, jak również, gdy dobro dziecka wymaga zapewnienia mu takiej pieczy niezwłocznie (art.112 $2^{3}$ k.r.o. $)^{36}$. Umieszczenie dziecka poza rodziną naturalną powinno stanowić środek ostateczny, stosowany, gdy dobro dziecka jest zagrożone. Dziecko umieszcza się w pieczy zastępczej do czasu zaistnienia warunków umożliwiających jego powrót do środowiska naturalnego ${ }^{37}$ albo do czasu umieszczenia go w rodzinie adopcyjnej. Jednakże dla dobra dziecka możliwe jest pozostawienie go w długoterminowym rodzinnym środowisku zastępczym do usamodzielnienia. Umieszczenie w pieczy zastępczej powinno uwzględniać prawo dziecka do opieki i wychowania w rodzinnych formach pieczy zastępczej - jeżeli jest to zgodne z dobrem dziecka. Piecza zastępcza zmierza do przygotowania dziecka do godnego, samodzielnego

32 Ustawa o wspieraniu rodziny i systemie pieczy zastępczej z dnia 9 czerwca 2011 r., (t.j. Dz. U. z 2018r., poz. 998), dalej jako u.w.r.p.z.

33 Ustawa o pomocy społecznej z dnia 12 marca 2004r., (t.j. Dz. U. z 2009r., Nr 175, poz. 1362 ze zm.).

34 J. Ignatowic, op. cit., s. 153.

35 Uchwała SN z dnia 9 czerwca 1976r., III CZP 46/75, OSNC 1976, nr 9, poz. 184; Wyrok SA w Białymstoku z dnia 28 października 2010r., Aca 458/10, LEX nr 784436.

36 Zob. Komentarz do Kodeksu Rodzinnego i Opiekuńczego - art.1123, K. Gromek, Warszawa 2018, Legalis.

37 M. Safjan, Podstawowe kierunki rozwoju opieki nad dzieckiem w rodzinach zastępczych, „PiP” 1980, z. 1., s. 84-85. 
i odpowiedzialnego życia, pokonywania trudności życiowych, nawiązywania i podtrzymywania kontaktów z rodziną i rówieśnikami oraz zdobywania umiejętności społecznych, a także dąży do zaspokojenia potrzeb emocjonalnych dzieci, potrzeb bytowych, zdrowotnych, edukacyjnych i kulturalno-rekreacyjnych.

\section{FORMY PIECZY ZASTĘPCZEJ}

Ustawa o wspieraniu rodziny i systemie pieczy zastępczej w art. $34^{38}$ ustanawia dwie formy sprawowania pieczy zastępczej - rodzinną oraz instytucjonalną. Formami rodzinnej pieczy zastępczej jest rodzina zastępcza ${ }^{39} \mathrm{i}$ rodzinny dom dziecka. Rodzinna piecza zastępcza ma za zadanie zapewnienie dziecku całodobowej opieki i wychowania, zapewnienia mu poczucia godności i wartości osobistej. Ponadto, ma na celu zapewnienie dziecku kształcenia, rozwoju jego uzdolnień i zainteresowań, gwarantować mu dostęp do świadczeń zdrowotnych, zaspokajać jego potrzeby emocjonalne, bytowe, rozwojowe, społeczne i religijne, a także zapewniać ochronę przed arbitralną $\mathrm{i}$ bezprawną ingerencją w życie prywatne dziecka oraz umożliwiać mu kontakt z rodzicami i innymi bliskimi osobami, chyba że z uwagi na dobro dziecka sąd postanowi inaczej zgodnie z art. 40 ust. 1 u.w.r.p.z. Dodać należy, iż pieczy zastępczej nie można postrzegać jako środka służącego zapewnieniu jedynie podstawowych potrzeb bytowych dziecka, a stawiane mu zadania należy rozumieć w sposób jak najbardziej kompleksowy. Dlatego też, jak zauważa K. Tryniszewska, rola rodzinnej pieczy zastępczej nie może sprowadzać się do minimum opieki i wychowania w sytuacji sprawowania pieczy nad dzieckiem uzdolnionym, a polegać powinna na zapewnieniu mu kształcenia, takiego, jakie mogłoby ono uzyskać w prawidłowo funkcjonującej rodzinie naturalnej ${ }^{40}$. Rodzinę zastępczą lub rodzinny dom dziecka tworzą małżonkowie lub osoby niepozostające w związku małżeńskim, u których umieszczono dziecko w celu sprawowania nad nim pieczy zastępczej. Ustawodawca przewiduje trzy kategorie rodzin zastępczych którymi, są rodzina zastępcza spokrewniona, niezawodowa i zawodowa, w tym pełniące funkcję pogotowia rodzinnego i zawodowe specjalistyczne. Pełnienie funkcji rodziny zastępczej oraz prowadzenie rodzinnego domu dziecka może zostać powierzone osobom, które dają rękojmię należytego sprawowania pieczy zastępczej, nie są i nie były pozbawione władzy rodzicielskiej oraz władza rodzicielska nie jest im ograniczona ani zawieszona, wypełniają obowiązek alimentacyjny - w przypadku gdy taki obowiązek w stosunku do nich wynika z tytułu egzekucyjnego, nie są ograniczone w zdolności do czynności

38 Zob. B. Królak, M. Rączka, Komentarz do art. 34 u.w.r.p.z., Legalis 2017.

39 T. Smyczyński, op. cit., s. 260.

40 K. Tryniszewska, Ustawa o wspieraniu rodziny i systemie pieczy zastępczej. Komentarz, Warszawa 2010, s. 123. 
prawnych. Nadto, osoby te muszą być zdolne do sprawowania właściwej opieki nad dzieckiem, co zostało potwierdzone poprzez zaświadczenie lekarskie o stanie zdrowia wystawione przez lekarza podstawowej opieki zdrowotnej, w rozumieniu przepisów ustawy z dnia 27 października 2017 r. o podstawowej opiece zdrowotnej ${ }^{41}$ oraz opinią o posiadaniu predyspozycji i motywacji do pełnienia funkcji rodziny zastępczej lub prowadzenia rodzinnego domu dziecka wystawioną przez psychologa. Osoby te muszą przebywać na terytorium RP, z tym że w przypadku cudzoziemców ich pobyt musi być legalny. Ponadto, muszą zapewniać odpowiednie warunki bytowe i mieszkaniowe umożliwiające dziecku zaspokajanie jego indywidualnych potrzeb. Pełnienie funkcji rodziny zastępczej niezawodowej lub zawodowej oraz prowadzenie rodzinnego domu dziecka może być powierzone osobom, które nie były skazane prawomocnym wyrokiem za umyślne przestępstwo. W przypadku rodziny zastępczej niezawodowej co najmniej jedna osoba tworząca tę rodzinę musi posiadać stałe źródło dochodów. Kandydaci na rodzinę zastępczą w celu podniesienia swoich kwalifikacji mają także, obowiązek odbyć szkolenie organizowane przez organizatora rodzinnej pieczy zastępczej lub ośrodek adopcyjny ${ }^{42}$.

Na rodzinie zastępczej lub prowadzącym rodzinny dom dziecka spoczywa obowiązek, a jednocześnie prawo wykonywania bieżącej pieczy nad dzieckiem, jego wychowania i reprezentowania, w szczególności w przedmiocie dochodzenia świadczeń przeznaczonych na zaspokajanie jego potrzeb ${ }^{43}$. Pozostałe obowiązki i prawa wynikające z władzy rodzicielskiej należą do rodziców dziecka. Objęcie dziecka jedną z form pieczy zastępczej następuje na okres nie dłuższy niż do osiągnięcia przez nie pełnoletności. Osoba dorosła może w warunkach określonych w art. 37 ust. 2 ustawy przebywać w dotychczasowej rodzinie zastępczej, rodzinnym domu dziecka albo placówce opiekuńczo-wychowawczej - nie dłużej niż do ukończenia 25 roku życia.

Umieszczenie w instytucjonalnej pieczy zastępczej następuje w sytuacji, gdy brak jest możliwości umieszczenia dziecka $\mathrm{w}$ rodzinnej pieczy zastępczej lub $\mathrm{z}$ innych ważnych powodów nie jest to zasadne ${ }^{44}$. Ustawodawca traktuje instytucjonalną pieczę zastępczą jako środek ostateczny, znajdujący zastosowanie wówczas, gdy z różnych przyczyn nie można znaleźć dla dziecka pieczy zastępczej5. Jednakże, zaakcentować należy, iż w doktrynie pojawił się pogląd negujący takie stanowisko. Zgodnie z M. Andrzejewskim instytucjonalna piecza zastępcza nie powinna być uznawana

${ }^{41}$ Ustawa z dnia 27 października 2017r., o podstawowej opiece zdrowotnej, (t.j. Dz. U. 2017r., poz. 2217 ze zm.).

42 T. Smyczyński, op. cit., s. 260.

43 J. Ignatowicz, M. Nazar, op. cit., s.166.

44 T. Smyczyński, op. cit., s. 259.

45 Zob. A. Regulska, [w:] Placówka opiekuńczo-wychowawcza, red. J. Kułaczkowski, Leksykon pedagogiki rodziny, Warszawa - Rzeszów 2011, s. 126-127. Por. także: P. Hanyga-Janczak, Dom dziecka jako placówka opiekuńczo-wychowawcza, red. B. Matyjas, Problemy teorii i praktyki opiekuńczej, Kielce 2005. 
za instrument prawny gorszej kategorii, gdyż w pewnych konkretnych przypadkach może okazać się środkiem bardziej wskazanym. Jak słusznie stwierdza autor, dziecko o ukształtowanym stosunku emocjonalnym do swoich rodziców biologicznych może traktować rodzinną pieczę zastępczą jako oręż wymierzony przeciwko jego naturalnemu pochodzeniu ${ }^{46}$. Zgodnie $z$ art. 93 pkt 1 u.w.r.p.z. instytucjonalna piecza zastępcza jest sprawowana $\mathrm{w}$ formie placówek opiekuńczo-wychowawczych, regionalnych placówek opiekuńczo-terapeutycznych, interwencyjnych ośrodków preadopcyjnych. Placówki opiekuńczo-wychowawcze mogą natomiast, przybrać postać placówek typu socjalizacyjnego, interwencyjnego, specjalistyczno-terapeutycznego oraz rodzinnego, a samo umieszczenie dziecka w placówkach wskazanych uprzednio związane jest z faktem, iż umieszcza się w nich dzieci wymagających szczególnej opieki lub mających trudności w przystosowaniu się do życia w rodzinie.

Placówka opiekuńczo-wychowawcza typu rodzinnego ma za zadanie wychowywać dzieci w różnym wieku, w tym także, dorastające i usamodzielniające się zgodnie z dyspozycją art. 102 u.w.r.p.z. Ponadto daje możliwość wychowywania się wspólnie przez rodzeństwo. Placówki te zbliżone są do rodzinnego domu dziecka, dlatego też mają obowiązek współpracować z koordynatorem rodzinnej pieczy zastępczej i asystentem rodziny, pomimo że nie są objęte opieką koordynatora ${ }^{47}$.

Placówka opiekuńczo-wychowawcza typu interwencyjnego ma na celu sprawowanie doraźnej opieki nad dzieckiem w czasie trwania sytuacji kryzysowej, w szczególności placówka ta jest zobowiązana przyjąć dziecko w przypadkach wymagających natychmiastowego zapewnieniu dziecku opieki, a pobyt w tej placówce, nie może trwać dłużej niż 3 miesiące. W szczególnie uzasadnionych przypadkach okres może zostać przedłużony do zakończenia trwającego postępowania sądowego o powrót dziecka do rodziny, przysposobienie oraz umieszczenie w pieczy zastępczej. Jak stanowi art. 103 pkt 2 u.w.r.p.z. przyjęcie do niniejszej placówki następuje na mocy orzeczenia sądu, ale także w przypadku doprowadzenia do niej dziecka w trybie art. 12a u.p.p.r.

Kolejnym rodzajem placówki opiekuńczo-wychowawczej jest placówka typu specjalistyczno-terapeutycznego, która sprawuje opiekę nad dzieckiem o indywidualnych potrzebach, w szczególności gdy, dziecko legitymuje się orzeczeniem o niepełnosprawności albo orzeczeniem o umiarkowanym lub znacznym stopniu niepełnosprawności, dzieckiem wymagającym stosowania specjalnych metod wychowawczych i specjalistycznych terapii oraz dzieckiem wymagającym wyrównania opóźnień rozwojowych i edukacyjnych stosownie do treści art. 104 u.w.r.p.z.

W placówce opiekuńczo-wychowawczej typu socjalizacyjnego, interwencyjnego lub specjalistyczno - terapeutycznego są umieszczane dzieci powyżej 10 roku życia, wymagające szczególnej opieki lub mające trudności w przystosowaniu się do życia

\footnotetext{
46 M. Andrzejewski, op. cit., s. 26.

47 J. Łukasiewicz red., Instytucje..., s. 232.
} 
w rodzinie. W tego rodzaju placówkach w tym samym czasie można umieścić łącznie nie więcej niż 14 dzieci, a w placówce opiekuńczo-wychowawczej typu rodzinnego można umieścić w tym samym czasie łącznie nie więcej niż 8 dzieci.

W regionalnej placówce opiekuńczo-terapeutycznej są umieszczane dzieci wymagające szczególnej opieki, które ze względu na stan zdrowia wymagają stosowania specjalistycznej opieki i rehabilitacji, a nie mogą zostać umieszczone w rodzinie zastępczej lub placówce opiekuńczo-wychowawczej. W omawianym rodzaju placówek nie można w tym samym czasie umieścić łącznie więcej niż 30 dzieci ${ }^{48}$.

W interwencyjnym ośrodku preadopcyjnym umieszcza się dzieci, które wymagają specjalistycznej opieki, a w okresie oczekiwania na przysposobienie nie mogą zostać umieszczone $\mathrm{w}$ rodzinnej pieczy zastępczej zgodnie $\mathrm{z}$ art. 111 ust. 1 u.w.r.p.z. W interwencyjnym ośrodku preadopcyjnym, w tym samym czasie, można umieścić nie więcej niż 20 dzieci, a pobyt dziecka w tym ośrodku nie może trwać dłużej, niż do ukończenia przez dziecko pierwszego roku życia.

Placówki opiekuńczo-wychowawcze zapewniają całodobową opiekę i wychowanie dzieciom, których rodzice trwale lub okresowo nie mogą, nie potrafią lub nie chcą stworzyć im właściwych warunków życia i rozwoju. Umieszczenie dziecka w placówce opiekuńczo-wychowawczej powinno służyć reintegracji rodziny, przywróceniu kompetencji wychowawczych rodzicom ${ }^{49}$. Zadania, które mają spełniać placówki opiekuńczo-wychowawcze to nie tylko zapewnienie dziecku całodobowej opieki i wychowania, ale także mają na celu zaspokojenie ich niezbędnych potrzeb w szczególności emocjonalnych, rozwojowych, zdrowotnych, bytowych, społecznych a także, religijnych. Ponadto piecza instytucjonalna ma na celu realizowanie przygotowanego we współpracy z asystentem rodziny planu pomocy dziecku, umożliwienie kontaktu dziecka z rodzicami i innymi osobami bliskimi, chyba że sąd postanowi inaczej, a nadto, podejmowanie działań mających na celu powrót dziecka do rodziny, zapewnieniu dziecku dostępu do kształcenia dostosowanego odpowiednio do jego wieku i możliwości rozwojowych, objęcie dziecka działaniami terapeutycznymi, zapewnieniu możliwości korzystania z przysługujących świadczeń (art. 93 ust. 4 u.w.r.p.z.).

Współcześnie instytucjonalna piecza zastępcza przechodzi poważne przeobrażenia i coraz częściej zapewnia dzieciom warunki maksymalnie zbliżone do domowych jednakże, należy mieć na uwadze, iż placówka nie stanie się nigdy ich naturalnym domem, a będzie jedynie jego zastępczą formą. Nawet najlepiej zorganizowana placówka nie zmieni niekorzystnego, zbiorowego charakteru opieki i wychowania występującego w instytucjonalnej pieczy zastępczej. Wspólne funkcjonowanie pod jednym dachem dzieci o niejednorodnych trudnościach i potrzebach często może sprzyjać naśladownictwu, a nawet przejmowaniu niekorzystnych zachowań przez podopiecznych.

48 J. Ignatowicz, op. cit., s. 174.

49 E. Dobrzycka, E. Kozdrowicz, Dom Dziecka, red. W. Pomykało, Warszawa 1997, s. 16. 


\section{PODSUMOWANIE}

Współcześnie piecza zastępcza za zadania priorytetowe musi stawiać sobie przede wszystkim skuteczność wsparcia dzieci i młodzieży. Wszelkie działania realizowane przez ustawodawcę na rzecz dzieci, powinny służyć budowie funkcjonalnego systemu opieki nad dzieckiem i rodziną, przede wszystkim systemu, który będzie przeciwdziałał konieczności umieszczenia dzieci w instytucjonalnej pieczy zastępczej, a jeżeli już zajdzie taka konieczność będzie generował oddziaływania na rzecz pracy z rodziną biologiczną i powrotem dziecka do domu rodzinnego. Ponadto piecza zastępcza $\mathrm{w}$ swoich działaniach powinna wspierać procesy prawidłowego usamodzielniania dzieci i młodzieży, aktywizowania ich, rozwijania ich pasji i zainteresowań, aby byli oni zdolni do samodzielnej egzystencji poza systemem pomocy społecznej, aby potrafili założyć własną rodzinę, w której nie będzie można dostrzec zjawiska dysfunkcjonalności, z którym oni mieli styczność. Dokonując zatem nowelizacji prawa, ustawodawca musi starać się ulepszyć, zmienić, dopasować do współczesnych problemów pieczę zastępczą w Polsce, pamiętając przede wszystkim o dobru dziecka i jego prawidłowym rozwoju emocjonalnym.

\section{BIBLIOGRAFIA}

Andrzejewski M., [w:] Pomocnicza rola państwa w świetle konwencji o prawach dziecka, Wspótczesne kierunki w opiece nad dzieckiem, red. Z. W. Stelmaszuka, Warszawa 1999.

Balcarek M., Prawa dziecka, Warszawa 1988.

Borysiak W., [w:] Komentarz do art. 18 Konstytucji RP, Konstytucja RP. Tom I. Komentarz do art. 1-86, red. Safjan M., Bosek L., Warszawa 2016.

Ciepła H., Ignaczewski J., Skibińska-Adamowicz J., Komentarz do spraw rodzinnych, Warszawa 2012.

Cudak H., Dysfunkcje rodziny i jej zagrożenia opiekuńczo-wychowawcze, „Pedagogika Rodziny 1⁄2”, 2011.

Dobrzycka E., Kozdrowicz K., Dom Dziecka, red. Pomykało W., Warszawa 1997.

Gromek K., Komentarz do Kodeksu Rodzinnego i Opiekuńczego, Warszawa 2018, Legalis.

Hanyga- -Janczak P., Dom dziecka jako placówka opiekuńczo-wychowawcza, red. Matyja B., Problemy teorii i praktyki opiekuńczej, Kielce 2005.

Ignatowicz I., Nazar M., Prawo rodzinne, Warszawa 2016.

Jarosz M., Problemy dezorganizacji rodziny, Warszawa 1979.

Kodeks rodzinny i opiekuńczy z komentarzem, red. Piaseckiego K., Warszawa 2002.

Kotlarska-Michalska A., [w:] Główne cechy rodzin dysfunkcyjnych i możliwości zintegrowania pomocy środowiskowo - instytucjonalnej, Zintegrowane działania oświaty i pomocy społecznej na rzecz polityki społecznej, „Biuletyn Informacyjny Służb Socjalnych” nr 1(4), Poznań 1997a.

Kołodziejski S., Dobro wspólnych małoletnich dzieci jako przesłanka odmowy orzeczenia rozwodu, „Palestra”, Nr 9/1965.

Kotlarska-Michalska A., Dysfunkcje rodziny jako efekt przemian makrostrukturalnych, Torun 2011.

Kozak S., Patologia eurosieroctwa w Polsce, Skutki migracji zarobkowej dla dzieci i ich rodzin, Warszawa 2010. 
Królak B., Rączka M., Komentarz do ustawy o wspieraniu rodziny i systemie pieczy zastępczej., Legalis 2017.

Mączyński A., Konstytucyjne podstawy prawa rodzinnego, Warszawa 2012.

Piotrowska K., Dobro Dziecka w orzecznictwie sędziego rodzinnego, „IUSTITIA” 2017, Nr 1.

Problemy Opiekuńczo Wychowawcze, „Instytut Rozwoju Służb Społecznych”, nr 5/2015.

Radwański, Pojęcie i funkcja „,dobra dziecka” w polskim prawie rodzinnym i opiekuńczym, „Studia Cywilistyczne", t. XXXI, Warszawa - Kraków 1981.

Regulska A., [w:] Placówka opiekuńczo-wychowawcza, red. Kułaczkowski J., Leksykon pedagogiki rodziny, Warszawa - Rzeszów 2011.

Rembowski J., Więzi uczuciowe w rodzinie, Warszawa 1972.

Rodzina i prawo, red. D. Jaroszewskiej - Choraś, A. Kilińskiej - Pękacz, A. Wedeł - Domaradzkiej, Bydgoszcz 2017.

Rodziny dysfunkcjonalne, red. Maślacka L., Wrocław 1991.

Safjan M., Podstawowe kierunki rozwoju opieki nad dzieckiem w rodzinach zastępczych, „PiP” 1980, z. 1.

Sakowicz T., Dysfunkcjonalność rodziny a resocjalizacja (Wybrane teksty z socjologii rodziny i resocjalizacji), Kraków 2006.

Smyczyński T., Prawo rodzinne i opiekuńcze, Warszawa 2016.

Stojanowska W., Rozwód a dobro dziecka, Warszawa 1979.

Szczepański J., Elementarne pojęcie socjologii, Warszawa 1970.

Tryniszewska K., Ustawa o wspieraniu rodziny i systemie pieczy zastepczej. Komentarz, Warszawa 2010. Zaborowski Z., Rodzina jako grupa społeczno-wychowawcza, Warszawa 1980.

Zieliński M., Ziembiński Z., Uzasadnienie twierdzeń, ocen i norm w prawoznawstwie, Warszawa, 1988.

Żardecka - Nowak M., [w:]Czy we wspótczesnej liberalnej demokracji jest miejsce dla wartości rodzinnych?, red. M. Malikowski, S. Gałkowski, Zagrożenia dla rodziny, Rzeszów 2010.

Uchwała SN z dnia 9 czerwca 1976r., III CZP 46/75, OSNC 1976, nr 9, poz. 184.

Uchwała SN (7) z dnia 14.11.2014 r., III CZP 65/14, Legalis.

Konstytucja Rzeczypospolitej Polskiej z dnia 2 kwietnia 1997r., (t.j. Dz. U. z 1997r., Nr 78, poz. 483 $\mathrm{z}$ zm.),

Konwencja o prawach Dziecka przyjęta przez Zgromadzenie Ogólne Narodów Zjednoczonych z dnia 20 listopada 1989r., (t.j. Dz. U. Z 1991r., Nr 120, poz. 526 z zm.).

Ustawa z dnia 25 lutego 1964r. - Kodeks rodzinny i opiekuńczy, (t.j. Dz. U. z 2018r., poz. 950 ze zm.). Ustawa o pomocy społecznej z dnia 12 marca 2004r., (t.j. Dz. U. z 2009r., Nr 175, poz. 1362 ze zm.). Ustawa z dnia 27 października 2017r., o podstawowej opiece zdrowotnej, (t.j. Dz. U. z 2017r., poz. 2217 ze zm.).

Postanowienie SN z dnia 7 czerwca 1967r., III CR 84/67, OSCP 1968, nr 2, poz. 21.

Postanowienie SN z dnia 11 lutego 1997r., II CKN 90/96, Legalis nr 333272.

Wyrok SA w Białymstoku z dnia 28 października 2010r., Aca 458/10, LEX nr 784436.

\section{SUMMARY}

In the article, the issues concerning child welfare, family dysfunctions and foster care in Polish legal system are discussed. The thesis characterizes the importance of the family, its functions and the role in the life of each child. The problem of family dysfunctions, improper attitudes and parental behaviours is disclosed. Moreover, the foster care institution is presented as a form of family support applied in the absence of due parental care and violation of the child welfare principle.

keywords: child welfare, family, family dysfunctions, foster care 